\title{
On the organic matter in tropical soils
}

\author{
K. H. TAN and J. VAN SCHUYLENBORGH \\ University of Indonesia, Bogor (Java) and Agricultural University, \\ Wageningen (Netherlands) respectively
}

\section{Summary}

The ideas of the authors about the soil forming processes under humid tropical climate could be supported by the results of the determination of the light absorption curves of organic matter preparations extracted from several Great Soil Groups.

\section{Introduction}

The study of the organic matter of the soil can be approached from the viewpoints of soil fertility, of soil physics, of soil microbiology and of soil genesis. It is the last item, that will be considered in this paper.

Much work has already been done on the effect of the organic matter in soil formation, especially podzolization in the temperate climates. For a review it be referred to Stobbe and Wright (1959) and SchefFer and Ulrich (1960).

The role of organic matter in the formation of tropical soils was studied by vaN SCHUYLENBORGH and co-workers $(1955,1957,1958,1959,1961)$. They concluded, that under circumstances of high and continuous humidity and high temperature the organic matter was predominantly mineralized if the parent material contained a considerable amount of bases as in andesitic volcanic material; the resulting carbonic acid was then the soil forming factor. Another reason, why organic matter was relatively inactive in tropical soil formation is their small mobility as a consequence of the high base saturation of the relatively young volcanic soils. At lower temperatures the organic matter appeared to be active, other conditions (rainfall and parent material) being equal.

In cases of acid parent materials, however, the organic matter is less rapidly mineralized, so that here again the well-known effect of organic acids on the translocation of iron and aluminium (see a.o. Aarnio, 1933 ; Ponomareva, 1949 ; Bloomfield, 1953, 1954, 1955; MARTIN and ReEve, 1957, 1960; MARTIN, 1960) could be observed.

As a consequence of the variations in climate and parent materials the toposequences, presented in TABLE 1, could be established and discussed.

It is the purpose of this paper to find further support for the theory of soil formation in the humid tropics developed in the publications mentioned earlier.

\section{Methods}

The organic matter of the horizons of several Great Soil Groups, presented in TABLE 1, was extracted with weak alkali-solutions and precipitated with acid as described earlier

Received for publication 10th May, 1961. 
TABLE 1. Tropical Great Soil Groups formed on different parent materials and climates under conditions of perfect drainage

\begin{tabular}{|c|c|c|c|}
\hline \multirow[t]{2}{*}{ Soil Group } & \multicolumn{3}{|c|}{ Humid climate } \\
\hline & $\begin{array}{l}\text { Parent } \\
\text { material }\end{array}$ & $\begin{array}{l}\text { Altitude } \\
\text { in meters }\end{array}$ & $\begin{array}{c}\text { Temperature } \\
\text { in }{ }^{\circ} \mathrm{C}\end{array}$ \\
\hline $\begin{array}{l}\text { Humic Grey Brown Podzolic soil } \ldots \ldots \ldots \ldots \\
\text { Tropical Grey Brown Podzolic soil } \ldots \ldots \ldots \ldots \\
\text { Acid Brown Earth } \ldots \ldots \ldots \ldots \ldots \ldots \ldots \ldots \\
\text { Podzolic Latosol } \ldots \ldots \ldots \ldots \ldots \ldots \\
\text { Reddish Brown and Red Latosol } \ldots \ldots \ldots \ldots \ldots\end{array}$ & $\begin{array}{c}\text { Andesitic tuff } \\
\qquad " \\
" \\
" \\
"\end{array}$ & $\begin{array}{l}>1300 \\
1300-1000 \\
1000-600 \\
600-350 \\
350-\quad 0\end{array}$ & $\begin{array}{l}<18,5 \\
18,5-20,5 \\
20,5-22,5 \\
22,5-24,0 \\
24,0-26,5\end{array}$ \\
\hline $\begin{array}{l}\text { Humus Iron Podzol } \ldots \ldots \ldots \ldots \ldots \ldots \\
\text { Podzol-Brown Podzolic Intergrade } \ldots \ldots \ldots \ldots \\
\text { Brown Podzolic Soil } \ldots \ldots \ldots \ldots \ldots \ldots \ldots \\
\text { Red and Yellow Podzolic Soil } \ldots \ldots \ldots \ldots \ldots\end{array}$ & $\begin{array}{c}\text { Liparitic tuff } \\
\text { " } \\
"\end{array}$ & $\begin{array}{r}2000-1500 \\
1500-1100 \\
1100-500 \\
500-\quad 0 \\
\text { neon clima }\end{array}$ & $\begin{array}{l}14,5-17,5 \\
17,5-20,0 \\
20,0-23,5 \\
23,5-26,5\end{array}$ \\
\hline $\begin{array}{l}\text { Brown Podzolic Soil } \ldots \ldots \ldots \\
\text { Non Calcic Brown Forest Soil } \ldots \ldots \ldots \ldots \ldots \ldots \\
\text { Latosolic Brown Forest Soil } \ldots \ldots \ldots \ldots \ldots \ldots \\
\text { Brown Latosol } \ldots \ldots \ldots \ldots \ldots \ldots \ldots \ldots \ldots \\
\text { Reddish Brown Latosol } \ldots \ldots \ldots \ldots \ldots \ldots \ldots\end{array}$ & $\begin{array}{c}\text { Andesitic tuff } \\
\qquad, \\
, \\
" \\
"\end{array}$ & $\begin{array}{r}3400-2500 \\
2500-1400 \\
1400-1000 \\
1000-600 \\
600-300\end{array}$ & $\begin{array}{r}6,0-11,5 \\
11,5-18,0 \\
18,0-20,5 \\
20,5-22,5 \\
22,5-24,5\end{array}$ \\
\hline
\end{tabular}

(TAN and VAN SCHUYLENBORGH, 1959). Various attempts to separate the extracted substances in grey and brown humic acids, by treatment with neutral salt solution (SPRINGER, 1938 ; FlaIG et al., 1955) failed. The extracted organic material appeared to be insoluble in neutral salt solution and would, therefore, belong to the group of the grey humic acids.

The U.V.- and visible light spectra of the different preparations were determined, using the Hilger UVISPEK. As the concentration could not be related to the molecular weight of the substances, $100 \mathrm{mg}$ of the preparations were dissolved in 1 liter of water. The logarithm of the extinction (lg $\varepsilon$ ) was plotted against the wave length. In this way the shape of the light absorption curve became indicative for the type of organic matter. The results are given in FIGs. 1,2 and 3.

The slopes of the curves are, according to SpRINGer (1937), Scheffer and Welte (1950) and Flaig et al. (1955), characteristic for the molecular weight of the organic substances. The slopes of light absorption curves of substances with a low molecular weight would be greater than that of substances with a high molecular weight. Or, the stronger polimerised substances show curves with small slopes and the slightly polimerised ones show steep curves. The slope of the curves will be presented by the difference of the logarithms of the extinetions at $400 \mu$ and $600 \mu$ and the "colour ratio" $\left(Q_{4 / 6}\right)$ represented by the ratio of the extinction at $400 \mu$ and that at $600 \mu$. SPRINGER (1934) used the "colour ratio"

$$
\frac{\text { extinction at } 472 \mu}{\text { extinction at } 666 \mu}
$$

and Flaig et al. (1955) used the ratio

$$
\frac{\text { extinction at } 475 \mu}{\text { extinction at } 675 \mu}
$$


The authors selected $400 \mu$ and $600 \mu$ as the wave lengths, because the curves in this range are as straight as possible.

The shape of the light absorption curves will be connected with the $\mathrm{C} / \mathrm{N}$-ratios of the organic preparations and both will be considered in relation to the relative mobilities of aluminium and iron. $A$ measure of these relative mobilities can be found in the molar ratios of $\mathrm{Al}_{2} \mathrm{O}_{3}$ and $\mathrm{Fe}_{2} \mathrm{O}_{3}$.

\section{Results and discussion}

\section{a. Humus Iron Podzols on liparitic tuff}

The curves of FIG. 1a suggest that the organic matter of the $B_{2 h}$-horizon represents a mixture of those in the $A_{2-}$ and $B_{2 i r}$-horizons. This seems to be supported by the $\mathrm{C} / \mathrm{N}$-ratios of the organic matter, being 19,4 in the $\mathbf{A}_{2}$-horizon, 24,5 in the $\mathbf{B}_{2 \mathrm{~h}}$ and 30,0 in the $B_{2 i r}$. It can be concluded that, under the conditions mentioned, the organic matter with the high $\mathrm{C} / \mathrm{N}$ ratio and low molecular weight is more mobile than the fraction with lower $\mathrm{C} / \mathrm{N}$-ratio and higher molecular weights. The molar $\mathrm{Al}_{2} \mathrm{O}_{3} / \mathrm{Fe}_{2} \mathrm{O}_{3}$ ratios for the horizons were $6,81,14,2$ and 4,60, respectively, which shows that iron has been accumulated in the $B_{2 \mathrm{ir}}$-horizon, whereas aluminium has been accumulated in the $A_{2-}$ and $B_{2 h}$-horizon. Apparently the organic fraction with the low molecular weight (and high $\mathrm{C} / \mathrm{N}$-ratio) is responsible for the translocation and deposition of iron under the conditions studied, and the fraction with the high molecular weight (and low C/N-ratio) for the retention of aluminium. Although Ponomareva (1949) suggests that especially the fulvic acids (very low molecular weight and very high $\mathrm{C} / \mathrm{N}$ ratio) are responsible for the translocation of iron, it appears here that also some humic acids can have the same property.

FIG. 1a. Light absorption of organic matter preparations of Humus Iron Podzols

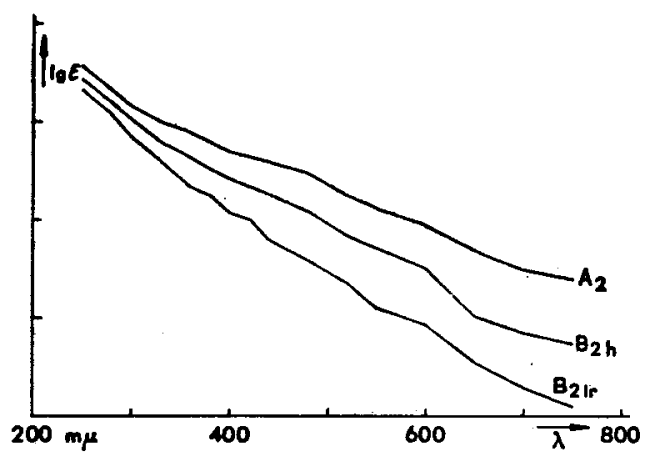

FIG. 1b. Light absorption of organic matter preparations of Humic Grey Brown Podzolic soils

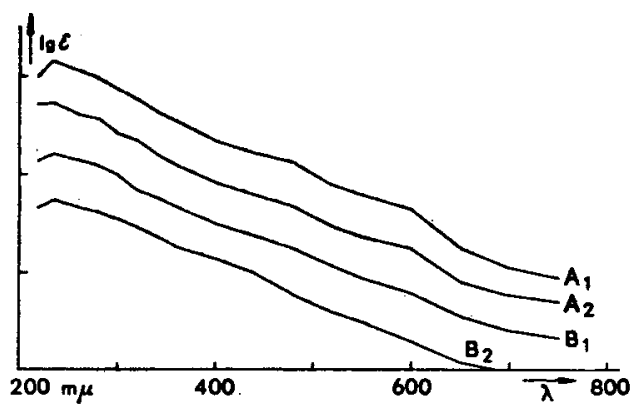

b. Humic Grey Brown Podzolic soils on andesitic tuff

The light absorption curves of FIG $1 b$ are nearly parallel and have a definite maximum at $230 \mu$, especially those of the $A_{1}, B_{1}$ and $B_{2}$-horizons. It seems that in this soil group only one group of organic substances predominate and has been produced in the $A_{1}$-horizon. Furthermore an admixture is present, which accumulates in the 
A2-horizon. Another difference with the organic matter of Humus Iron Podzols is the low $\mathrm{C} / \mathrm{N}$-ratio, viz. 10,7 in the $A_{1}, 8,4$ in the $A_{2}, 7,8$ in the $B_{1}$ and 6,9 in the $\mathrm{B}_{2}$-horizon. It appears that the members with the low $\mathrm{C} / \mathrm{N}$-ratio are more mobile than the members with the higher $\mathrm{C} / \mathrm{N}$-ratio. If the mobile types form more stable complexes with iron under these conditions and the less mobile types form stable complexes with aluminium, the unequal mobilities of iron and aluminium could be explained. The $\mathrm{Al}_{2} \mathrm{O}_{3} / \mathrm{Fe}_{2} \mathrm{O}_{3}$ ratios for the $\mathrm{A}_{1}, \mathrm{~A}_{2}, \mathrm{~B}_{1}$ and $\mathrm{B}_{2}$-horizon are : 5,19$5,87-5,28$ and 4,87 respectively, indicating that iron is more mobile than aluminium. Aluminium appears to be accumulated in the A2-horizon.

\section{c. Non Calcic Brown Forest soils on andesitic tuff}

Neither the light absorption curves (FIG. $2 \mathrm{a}$ ), nor the $\mathrm{C} / \mathrm{N}$-ratios (viz. 18,2 in the $\mathrm{A}_{1}$, 18,1 in the $B_{1}$, and 17,1 in the $B_{2}$ ) point to great differences of the organic substances of the horizons. Also the already small mobility of iron and aluminium is nearly equal, as is indicated by the $\mathrm{Al}_{2} \mathrm{O}_{3} / \mathrm{Fe}_{2} \mathrm{O}_{3}$ ratios, viz. 4,35 in the $\mathrm{A}_{1}: 4,26$ in the $B_{1}$, and 4,43 in the $B_{2}$-horizon. The profiles are characterized by only slight differentiation in horizons.

\section{d. Tropical Grey-brown Podzolic soils on andesitic tuff}

The light absorption curves (FIG. $2 a$ ) as well as the $\mathrm{C} / \mathrm{N}$-ratios (viz. : $\mathbf{A}_{1}$ : 15,9 ; $\mathbf{A}_{2}$ : 14,$\left.1 ; \mathbf{B}_{1}: 14,7 ; \mathbf{B}_{2}: 14,6\right)$ suggest that the same group of organic substances is present in all the horizons. No special fraction seems to be more mobile than another to account for the fact, that aluminium is more mobile than iron. The $\mathrm{Al}_{2} \mathrm{O}_{3} / \mathrm{Fe}_{2} \mathrm{O}_{3}$ ratios are : $A_{1}: 4,75 ; A_{2}: 5,85 ; B_{1}: 7,47 ; B_{2}: 8,26 ;$ and $C: 11,5$ which shows that there exists an overall loss of sesquioxides by hydrolysis and dissolution. It was pointed out earlier (VAN SCHUYLENBORGH, 1958) that this particular behaviour of $\mathrm{Al}$ and $\mathrm{Fe}$ can be explained by the supposition, that the types of organic substances are equally mobile and that the soil forming agent is carbonic acid, produced by the rapid microbial attack of the soil organic matter.

FIG. 2a. Light absorption of organic matter preparations of Non Calcic Brown Forest Soils and Tropical Grey Brown Podzolic Soils
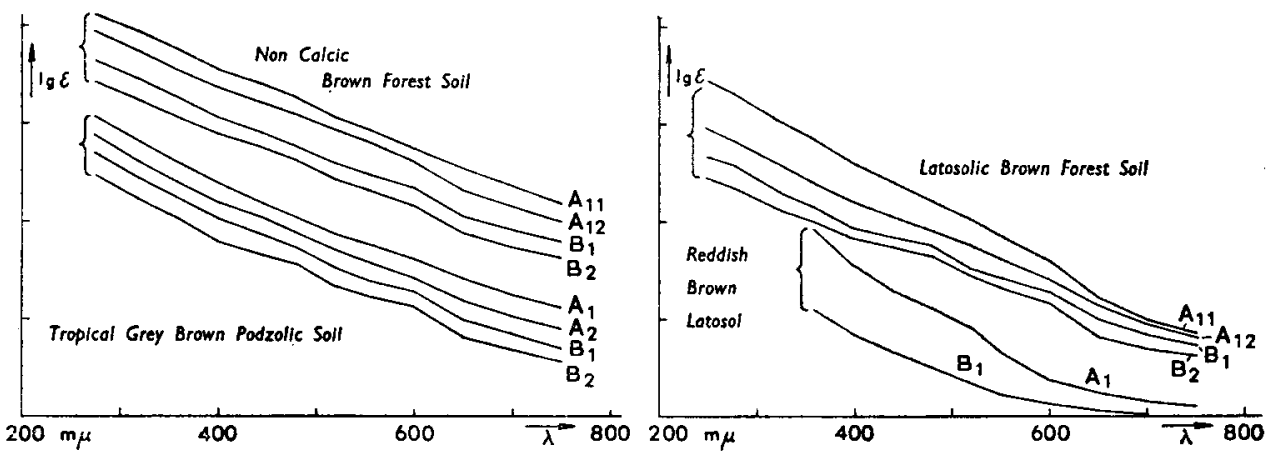

Fic. 2b. Light absorption of organic matter preparations of Latosolic Brown Forest Soils and Reddish Brown Latosols 


\section{e. Latosolic soils on andesitic tuff}

FIG. $2 b$ shows that the slope of the light absorption curves decreases from the $A_{1}$ to the $B_{2}$-horizon; also the $C / N$ ratios decrease, viz. $24,4-18,0$ and 17,1 for the $A_{1}, B_{1}$ and $B_{2}$-horizon, respectively, of the Latosolic Brown Forest soils and 9,0-6,4 and 6,3 for the $A_{1}, B_{1}$ and $B_{2}$-horizons, respectively, of the Reddish Brown Latosols. It seems that in these soils a fraction with a lower $\mathrm{C} / \mathrm{N}$-ratio is mobile. This fraction may be responsible for the migration of iron, as iron appears to be more mobile than aluminium (the $\mathrm{Al}_{2} \mathrm{O}_{3} / \mathrm{Fe}_{2} \mathrm{O}_{3}$ ratios are : $6,20-5,85$ and 5,82 ; and $5,36-5,13$ and 5,09 for the $A_{1}, B_{1}$ and $B_{2}$-horizons of Latosolic Brown Forest soils and Reddish Brown Latosols, respectively). Here, too, carbonic acid may be acting as soil former, but the action of organic acids seems to be stronger.

\section{f. Podzolic Latosols and Acid Brown Earths on andesitic tuff}

The light absorption curves show more or less the same appearance (FIG. 3) and are comparable with those of the Latosolic soils (see e). The difference in slope of the curves within the profile is, however, smaller, as are the $\mathrm{C} / \mathrm{N}$-ratios. These ratios are : 12,9-11,8 and 11,5 for the $A_{1}, B_{1}$ and $B_{2}$-horizons of the Podzolic Latosol and 11,09,5 and 8,4 for the $A_{1}, B_{1}$ and $B_{2}$ of the Acid Brown Earth, respectively. In both soil groups aluminium is more mobile than iron as can be seen from the $\mathrm{Al}_{2} \mathrm{O}_{3}$ / $\mathrm{Fe}_{2} \mathrm{O}_{3}$-ratios. These are for the Acid Brown Earth: $\mathrm{A}_{1}: 5,44 ; \mathrm{B}_{1}: 6,23 ; \mathrm{B}_{2}: 6,66$; $\mathrm{C}: 11,2$ and for the Podzolic Latosol: $\mathbf{A}_{1}: 5,10 ; \mathbf{B}_{1}: 5,37 ; \mathbf{B}_{2}: 6,36$ and $\mathrm{C}: 9,17$. It appears therefore, that, although there is a certain transport of organic matter with a low $\mathrm{C} / \mathrm{N}$-ratio and higher molecular weight, which would have led to the transference of iron, the formation of carbonic acid is still so excessive, that aluminium becomes more mobile than iron. The Acid Brown Earths and the Podzolic Latosols form intermediate cases between the Tropical Grey Brown Podzolic soils and the Latosols.

\section{g. Brown Podzolic Soils on liparitic tuff}

Although the light absorption curves are not available up to now, we can nevertheless state, that the same mechanism for aluminium and iron transport could be established as in the foregoing groups of soils. Here too, the $\mathrm{C} / \mathrm{N}$ ratios decrease only slightly with depth, and there is a relative enrichment of aluminium over iron. The data are : $11,4-9,5$ and 10,0 for the $C / N-$ ratios and 8,96-9,83 and 9,66 for the $\mathrm{Al}_{2} \mathrm{O}_{3} / \mathrm{Fe}_{2} \mathrm{O}_{3}$ ratios in the $\mathrm{A}_{1}, \mathrm{~B}_{1}$ and $\mathrm{B}_{3}$-horizons, respectively.

Finally it can be stated, that there exists a relation between the type of organic matter present in the soils investigated and the temperature (elevation above sea level).

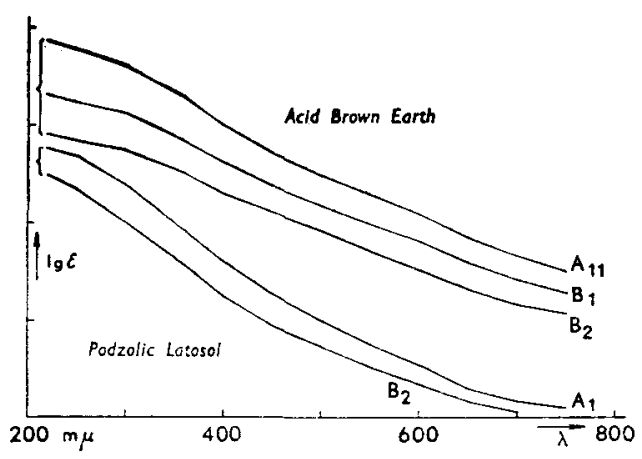

Fig. 3. Light absorption of organic matter preparations of Acid Brown Earths and Podzolic Latosols 
TABLE 2. $\operatorname{Lg} \varepsilon_{400}-\lg \varepsilon_{60 n}$ and $\mathrm{Q}_{4 / 6}$-values of some Great Soil Groups, formed on andesitic volcanic tuff under the conditions listed

\begin{tabular}{|c|c|c|c|}
\hline \multirow[t]{2}{*}{ Soil Group } & \multicolumn{3}{|c|}{ Humid climate } \\
\hline & $\begin{array}{l}\text { Temperature } \\
\text { in }{ }^{\circ} \mathrm{C}\end{array}$ & $\lg \varepsilon_{400}-\lg \varepsilon_{600}$ & $\mathbf{Q}_{4 / 6}$ \\
\hline $\begin{array}{l}\text { Grey Brown Podzolic Soil } \ldots \ldots \ldots \ldots \ldots \ldots \\
\text { Acid Brown Earth } \ldots \ldots \ldots \ldots \ldots \ldots \ldots \ldots \ldots \ldots \\
\text { Podzolic Latosol } \quad \ldots \ldots \ldots \ldots \ldots \ldots \ldots \ldots \ldots \ldots \\
\text { Latosol } \ldots \ldots \ldots \ldots \ldots \ldots \ldots \ldots \ldots \ldots\end{array}$ & $\begin{array}{l}14,5-20,5 \\
20,5-22,5 \\
22,5-24,0 \\
24,0-26,5\end{array}$ & $\begin{array}{l}0,57-0,59 \\
0,65 \\
0,78 \\
0,75\end{array}$ & $\begin{array}{c}3,72-3,89 \\
4,47 \\
6,03 \\
5,62\end{array}$ \\
\hline & \multicolumn{3}{|c|}{ Monsoon climate } \\
\hline $\begin{array}{l}\text { Non Calcic Brown Forest soil } \ldots \ldots \ldots \ldots \ldots \\
\text { Latosolic Brown Forest soil } \ldots \ldots \ldots \ldots \ldots \ldots \\
\text { Brown Latosol } \ldots \ldots \ldots \ldots \ldots \ldots \ldots \ldots \ldots \ldots\end{array}$ & $\begin{array}{l}11,5-18,0 \\
18,0-20,5 \\
20,5-22,5\end{array}$ & $\begin{array}{c}0,57-0,61 \\
0,76 \\
0,95\end{array}$ & $\begin{array}{l}3,71-4,07 \\
5,75 \\
8,91\end{array}$ \\
\hline
\end{tabular}

TABLE 2 gives the $\lg \varepsilon_{400}-\lg \varepsilon_{600}$-values and the "colour ratios" $Q_{4 / 6}$ at different temperatures. It is evident, that these values increase with increasing temperature. This means that, as a whole, the organic matter of soils, formed under high temperatures, has lower molecular weights than the organic matter of soils, formed under lower temperatures, the parent material being equal. In other words, mineralization of organic matter, resulting in substances of low molecular weight and finally in carbonic acid, is predominant at high temperatures which is quite in agreement with the authors' theory. Even the fact that the "colour ratio" of the Reddish Brown Latosols is smaller than that of the higher situated Podzolic Latosol is in agreement with the above. These correlations are further supported by the results of the determination of $\mathrm{CO}_{2}$-content in soil air of diverse soil groups (see TABLE 3). It appears, that the Acid Brown Earths and the Podzolic Latosols contain the highest amounts of $\mathrm{CO}_{2}$ in soil air.

TABle 3. $\mathrm{CO}_{2}$-content (volume percentage) of the atmosphere in some tropical soils

\begin{tabular}{|c|c|}
\hline Soil Group & $\mathrm{CO}_{2}$-content \\
\hline $\begin{array}{l}\text { Tropical Grey Brown Podzolic Soil } \ldots \ldots \ldots \ldots \\
\text { Acid Brown Earth } \ldots \ldots \ldots \ldots \ldots \ldots \ldots \ldots \ldots \ldots \ldots \\
\text { Podzolic Latosol } \quad \ldots \ldots \ldots \ldots \ldots \ldots \ldots \ldots \ldots \ldots \\
\text { Latosol } \ldots \ldots \ldots \ldots \ldots \ldots \ldots \ldots \ldots\end{array}$ & $\begin{array}{l}0,84 \\
2,81 \\
2,50 \\
2,24\end{array}$ \\
\hline
\end{tabular}

Comparing the $\mathrm{Q}_{4 \mid 6}$ values of the soils of the humid and monsoon climates, we see furthermore that these values are higher in the monsoon than in the humid climate. The lower humidity of the monsoon climates seems to favour the mineralization of the organic matter, which is quite understandable.

\section{I T E R A T U R E}

Aarnio, B. BLOOMFIELD, C.
1913 Int. Mitt. Bodenk. 3, 131.

1953 J. Soil Sci. 4, 5, 17.

1954 J. Soil Sci. 5, 39, 46, 50.

1955 J. Soil Sci. 6, 284. 
Flaig, W., F. Scheffer and R. KLAMroth

MARTIN, A. E. and R. REEVE

Ponomareya, V. V.

SCHEFFER, F., and B. ULRICH

SCHEFFER, F., and E. WeLte

SCHUYLENBORGH, J. VAN

SchUYlenborgh, J. VAN, and F. F. F. E. VAN RUMMELEN

SPRINGER, U.

Stobbe, P. C., and J. R. WRIGHT

TAN KIM HoNG and J. VAN SChUYLENBorgh

TAN, K. H., and J. VAN SCHUYLENBORGH
1955 Z. Pflern. Düng. Bodenk. N.F. 71. (116.) Bd., p. 33.

1960 J. Soil Sci. 11, 382.

1957 J. Soil Sci. 8, 279.

1960 J. Soil Sci. 11, 369.

1949 Pochvovedenie. p. 638.

1960 Humus und Humusdüngung. Band I. Stuttgart.

1950 Z. Pflern. Düng. Bodenk. N.F. 48. (93.) Bd., p. 250.

1957 Neth. J. agric. Sci. 5, 195.

1958 Neth. J. agric. Sci. 6, 99.

1955 Neth. J. agric. Sci. 3, 192.

1934 Z. Pflern. Düng. Bodenk. 34, p. 1.

1937 Bodenk. Pflern. N.F. 3 (48.) Bd., p. 139.

1938 Bodenk. Pflern. N.F. 6. (51.) Bd., p. 312.

1959 Soil Sci. Soc. Amer. Proc. 23, 161.

1959 Neth. J. agric. Sci. 7, 1.

1961 Neth. J. agric. Sci. 9, 41. 